\title{
The Lecturers Performance Actualization in Building Academic Culture In State Islamic Religious College
}

\author{
M. Sugeng Sholehuddin', Agus Khairul², Anwar Sunawar Rizky³ ${ }^{3}$ Ah. Sahaludin ${ }^{4}$, Syahid $^{5}$, R. Asep \\ Hidayat Sugiri $^{6}$, Ulmah Nurhayati ${ }^{7}$, Iskandar ${ }^{8}$, Afith Akhwanudin ${ }^{9}$, Uswatun Hasanah ${ }^{10}$
}

${ }^{1,9,10}$ State Islamic Institute of Pekalongan, Indonesia

2,3,4,5,6,7,8 UIN Sultan Maulana Hasanuddin Banten, Indonesia

CorespondingAuthor : $\underline{\text { m.sugeng.s@ } @ \text { iainpekalongan.ac.id }}$

\begin{abstract}
:
This study aims to identify the quality of lecturers in carrying out the functions of the Tri Dharma of Higher Education, assess the relevance of the academic quality of lecturers in carrying out the teaching and learning process with students, and reveal the level of involvement or participation of the academic components of lecturers in study programs related to culture. academic and its urgency for the development of PAI and PBA FTIK IAIN Pekalongan study programs. This research is a descriptive participatory action research. The object of this research is the academic community in the Arabic Language Education and Islamic Religious Education study program IAIN Pekalongan. This research is also a qualitative research, with data analysis techniques using data reduction, data display, and data verification or inference. The results of this study found that the quality of the performance of the lecturers of the Islamic Religious Education Study Program and Arabic Language Education based on the Lecturer Performance Index (IKD) of the Quality Assurance Institute (LPM) of IAIN Pekalongan is very feasible and good. The relationship between lecturer performance and the formation of academic culture in the Islamic Religious Education Study Program and Arabic Language Education is interrelated and has a positive relevance between the two. The highest obstacle in building an academic culture in the Islamic Religious Education Study Program and Arabic Language Education FTIK IAIN Pekalongan is that lecturers in carrying out lectures do not match the number of meetings that should be held by lecturers, and there needs to be a special increase in terms of initiatives (initiative).
\end{abstract}

Keywords:

Management, Performance, Academic Culture, PAI, and PBA.

Article Received: 18 October 2020, Revised: 3 November 2020, Accepted: 24 December 2020

\section{A. INTRODUCTION}

Education plays an important role in determining the progress of the people and the nation. A quality education system produces quality output, namely a good young generation, and vice versa. Education is a very important part of maintaining sustainability in society (Maliki, 2010: 89). Education is a vital variable for the development of a nation. The low productivity of the poor for example, one of the factors is their low access to education. Without sufficient knowledge to survive, progress and develop, society cannot survive in the global dynamics so as to develop self-potential. A nation can progress quickly compared to other countries because of the spread of knowledge that is evenly distributed throughout all levels of society. The institutions most responsible for the dissemination of knowledge are educational institutions. However, the availability of ready institutions and resources does not mean to solve the problem, because the guarantee of access and comprehensive distribution must also be guaranteed (Sen, 1980: 218). On the other hand, most educational institutions are often managed without the support of reliable management and often ignore the basic principles of management (Muhab, et al., 2010: 17).

One of the educational problems faced by the nation is the low quality of education (Istikomah \& Ayuwanti, 2017: 99). This fact is quite concerning. Educational institutions need to 
implement modern management. One of the efforts that can be used as an alternative in improving the quality of education is by improving the existing governance in the educational institution. Good management (management) at least determines the quality of education administratively and becomes a guide in the education system. The quality of education is a determining element of today's modern era (Haseena \& Mohammed, 2015: 100). The quality of education also depends on the school leadership (Nursaid, 2020: 95).

In the era of globalization, an institution that only relies on the number of products without being accompanied by quality control is a big carelessness. In Malaysia, for example, directive supervision is positively and significantly related to the performance and attitudes of teachers (Hoque, et al., 2020: 1). The results of research by Khun-inkeeree et al., (2019: 1335) also show that there is a significant influence between the dimensions of knowledge and technical skills and the attitude of teachers towards supervision. Educational supervision is one of the most important supports for the education system and professional development of educators (Ismail, 2018: 115). Therefore, the involvement of top management is very large and decisive in placing a higher education institution. IAIN Pekalongan as one of the higher education institutions in Pekalongan and one of state Islamic religious colleges in Indonesia certainly must also refer to it. Management in question is related to professional academic structuring, both in the form of direct and indirect learning activities.

Related to this, the Islamic Religious Education Study Program (PAI) and Arabic Language Education (PBA) of the Tarbiyah and Educational Sciences Faculty (FTIK) IAIN Pekalongan are in a competitive position with a long journey. It has been 23 years PAI study program (1997-2020), and 10 years PBA study program (2010-2020) has tried to provide educational services. However, the length of experience was not very satisfying when compared to the standard operating procedures that had been established for the two study programs.

In this era, good quality and quality are the main orientation of the education system in all countries (Ekaviana \& Nurkhin, 2016: 43). PAI and PBA study programs as part of higher education institutions that issue graduate from college, without being based on quality considerations, must be ready to be left behind. Meanwhile, study programs that produce their graduate from college with controlled quality must also have the courage to face increasingly fierce quality competition (Sallis, 2012: 230). Therefore, awareness of a study program is very significant in improving the quality of its students. The quality of output must indirectly be supported by a conducive academic environment. The less supportive educational environment will certainly slow down and even hinder the vision of education itself.

Higher Education with a series of study programs is essentially a service institution. What is prioritized is to provide services according to the needs of consumers (students and stakeholders). Services performed with adequate expertise and skills will determine the attitudes of students and stakeholders. The services provided by the PAI and PBA study programs are educational services. The forms are: first, curricular services (JK) such as curriculum and syllabus; second, Services (JP): and laboratories; third, Community Service Services (JPM); fourth, Administrative Services (JA); and fifth, Extracurricular Services (JE). The more attractive the services provided, the more consumers (students) will be more interested in visiting a study program (Nasution, 2005: 75-89). The form of these services as a whole is part of the supporting elements of the academic environment that determine the quality of education output.

The activities of educational institutions in producing quality products should pay attention to systems and processes. Poor quality (wrong) systems and processes often make the perpetrators act wrong. Conversely, if all the systems and processes of an educational institution run well 
(quality), the resulting product is guaranteed to be of good quality. Based on the above matters, the main capital that a university study program must have is an academic atmosphere that is able to spur the development of intellectualism and produce useful work based on a solid management model and of course a commitment to the quality to be achieved in learning activities for students and stakeholders. For this reason, it is necessary to establish an internal reflection related to the optimal formation of the academic culture in the two study programs above which is carried out thoroughly by the management of the PAI and PBA study programs. Comprehensive in the sense that it involves all aspects of management in the PAI and PBA study programs; leaders, educational staff or administrative staff and lecturers. Improvement steps which are one of the alternatives are participatory, where improvements are made from-by-for the parties in the two study programs in controlling the academic performance of lecturers, both directly related to classroom learning and the competence of the lecturer as an academic; researchers and academic scientific developers. It is hoped that with a participatory approach, awareness that emerges is from internal management by providing input to each other and complementing existing gaps.

The idea of building an academic culture of the PAI and PBA FTIK IAIN Pekalongan study program through participatory is a new phenomenon. Its implementation needs to be supported by educational components such as the head of the department, lecturers, students, curriculum, facilities and infrastructure as well as support from stakeholders as partners in carrying out work programs in PAI and PBA study programs.

The focus of this research is the PAI and PBA FTIK IAIN Pekalongan study program because it is unique, namely "successful" in implementing the management capabilities of the study program which is based on three things, namely; First, the ability of the Head of the Study Program Development Team (KTPPS) to carry out management functions (planning, organizing, implementing and supervising). Second, the quality management of the PAI and PBA study programs to improve the ability of lecturers to carry out the teaching and learning process with students in appropriate learning strategies. Third, the level of involvement or participation of the components in the study program to build an academic culture and development of the PAI and PBA FTIK IAIN Pekalongan study program.

The main problem in this research is how to manage lecturer performance in building an academic culture in the PAI and PBA FTIK IAIN Pekalongan study program. The subject matter is translated into the following research questions; the first, how is the quality of lecturer performance in PAI and PBA FTIK IAIN Pekalongan Study Program? Second, is there the relevance of lecturer performance with the academic culture in PAI and PBA FTIK IAIN Pekalongan Study Program? Furthermore, the focus of this research is to identify the existing academic culture in FTIK. Given the limited time and resources, this research is focused on PAI and PBA Study Programs.

\section{B. RESEARCH METHOD}

This research is a Participatory Action Research (PAR). This research is also descriptive which is designed to determine the nature or situation at the time the investigation was carried out (Furchan, 2004: 447). The object of this research is the academic community in the Arabic Language Education and Islamic Religious Education study program at IAIN Pekalongan. The community in it includes the head of the study program, lecturers, administrative staff and students. This study will examine how academic management and lecturer performance indexes in building an existing academic culture in FTIK, especially in the Study Program of Islamic Religious Education and Arabic Language Education. In this study, the authors focused the object of research on the management of lecturer performance in building an academic culture in the Study Program of Islamic Religious Education 
and Arabic Language Education, FTIK IAIN Pekalongan. Because this research is a qualitative research, data analysis is carried out in three steps, as according to Miles and Huberman (1986), namely: data reduction, data display or presentation and data verification or inference (Ali, 1993: 167).

Management is a process of planning and decision making, organizing, leading and controlling human, financial, physical and information resource organizations to achieve organizational goals efficiently and effectively (Griffin, 2015: 6).

Planning, every beginning of the year the FTIK leadership together with the Head of the Study Program compile the FTIK quality plan. The quality plan is drawn up referring to the real need for improvement and development of academic quality which refers to the academic development policy of the Quality Assurance Institute (LPM) IAIN Pekalongan. The results are then submitted to the Quality Assurance Agency for assessment, improvement and approval. The quality plan covers all aspects of the implementation of learning and academic activities. Planning is part of FTIK's efforts to create optimal and well-conditioned academic implementation. To ensure the implementation of the quality plan, an internal good quality audit is carried out. Audit is intended to assess / measure, analyze and interpret organizational activities in the academic and non-academic fields objectively in the framework of performance appraisal for the purpose of evaluating and controlling organizational activities, so that organizational processes, goals and objectives can be achieved efficiently and effectively.

Organizing, the implementation of the organization in the Islamic Religious Education Study Program and the Arabic Language Education Study Program is led by the Head of the Study Program who is assisted by study program staff. Academic activities at the Study Program level are under the responsibility of the Head of the Study Program. As the head of the study program, the Head of the Arabic Language
Education Study Program establishes operational steps in implementing academic programs at the study program level by coordinating with study program lecturers to improve their performance. The Head of the Study Program also communicates effectively, both internally and externally as well as implements and develops cooperation with other parties, namely the Head of FTIK and the leaders of IAIN Pekalongan.

Actuating, the Islamic Religious Education Study Program and the Arabic Language Education Study Program within the scope of FTIK always carry out briefings related to planning and evaluating academic activities in FTIK. This is done to form a continuity of vision and mission and goals between educational institutions and the academic community and managers in it. In addition, it is also to stimulate open contributions for the improvement and development of management in the Study Programs and Departments. The briefing was carried out in the form of lecture preparation meetings with lecturers and regular evaluation meetings between lecturers and leaders.

Supervision or controlling, the supervision in the Islamic Religious Education Study Program and the Arabic Language Education Study Program include two things; internal and external. Internally, the study program is under the coordination of the Head of the Study Program and the head of the department in the form of monitoring program implementation activities. Internal supervision and control is carried out through Study Program Coordination Meetings, Department Coordination Meetings, IAIN Coordination Meetings, and IAIN Work Meetings.

Externally, supervision is carried out through a survey conducted at the department level with a questionnaire conducted by the FTIK Quality Group Team and at the IAIN Pekalongan level by the Quality Assurance Agency (LPM). Both of them delivered questionnaires related to the realization of classroom learning. In addition, there is also a Student Satisfaction Index (IKM) 
survey by LPM related to the quality of academic services in each unit at IAIN Pekalongan.

The aspects of supervision and control carried out by the study program include academic and non-academic fields. The academic field includes 3 aspects of the Tri Dharma of higher education including teaching, research and community service. The teaching-education learning aspects include curriculum implementation, learning syllabus, handouts, learning evaluation. Research aspects include the quantity and quality of research and scientific publications carried out. Meanwhile, the aspect of community service includes the quantity and quality of the role of lecturers in contributing to the development and empowerment of society with the knowledge and capabilities they have. The track record of lecturers in implementing the Tri Dharma is manifested by the Lecturer Performance Report (LKD) every semester and the Lecturer Academic Performance Index (IKAD) report every year.

\section{RESULTS AND DISCUSSION}

In this competitive global era, every institution, including educational institutions such as IAIN Pekalongan, needs human resources (HR), especially qualified lecturers. At the same time, each of these human resources needs feedback on their performance as a guide for their future actions. Therefore, the assessment should describe the performance of the personnel. The results of the performance appraisal can show whether the existing human resources have met the demands desired by the institution, both in terms of quality and quantity. Information in personnel performance appraisals is a reflection of whether the institution is developing or not.

The lecturer performance appraisal which is carried out every semester which is carried out on lecturers at IAIN Pekalongan is carried out on the basis of supervision, meaning that the assessment carried out on the lecturers is not only aimed at assessing performance, it also serves to supervise the lecturers in carrying out their main tasks, namely educational and teaching activities, therefore the criteria are used to evaluate, as well as function as a tool to monitor lecturer performance. The lecturer performance assessment will then produce a number called the Lecturer Performance Index (IKD). The aspects that are assessed in the IKD are only related to the learning process, because other aspects such as research and community service have been covered in the lecturer workload report (BKD). Supervision-based lecturer performance evaluation can be carried out by department leaders, students and assigned staff.

Social problem analysis is an important stage in PAR research. At this stage the researcher tries to find problems and obstacles that are felt by the community. In this study, the people who are the object of research are the academic community (students and lecturers) in the Islamic Religious Education Study Program and Arabic Language Education. Researchers provide a stimulus to raise existing awareness in society regarding certain problems. In this case the researcher proposes stimulation of the relevance of lecturer performance in building academic culture in the Study Program of Islamic Religious Education and Arabic Language Education.

The analysis of this research was carried out in 2 stages; the first stage, from among students and the second stage, from the Study Program Student Association (HMPS) and Lecturers. In the first stage, the researcher provided a stimulus for students in the PAI and PBA Study Programs to evaluate together the draft quality plan in FTIK. The FTIK quality plan is the main reference in building academics. It was continued in the second stage which was specifically in the form of a forum with the Study Program Student Association (HMPS) of PAI and PBA Study Programs and lecturers in the two study programs. This stage is to re-review and enrich references on existing aspects related to the relevance of lecturer performance in building 
academic culture.

From the questionnaires and meetings conducted with the academic community in the Study Program of Islamic Religious Education and Arabic Language Education, there are aspects that become benchmarks for lecturer performance in building academic culture, including:

1. The quality of work (quality of work)
a. Availability of Syllabus and SAP
b. Availability of course handouts or teaching materials
c. The materials and approaches used are up to date

2. Ability (capability)
a. Lecturer Qualifications (Scientific Conformity with Subjects)

b. Mastery of the material
c. Mastery in responding to questions during discussion / presentation

d. Class management skills

e. Mastery of media and learning technology

f. Academic assessments carried out objectively

3. Initiatives (initiatives)

a. The syllabus is the result of the coordination of parallel courses

b. Standardization of exam questions for the same subject with different lecturers

c. Paper writing rules are in accordance with academic writing guidelines

d. Foreign language reference suggestions

e. Tasks that are analytical, research, or product manufacturing

f. Involving students in the study of academic activities

\section{Communication (communication)}

a. Delivering lecture materials properly and clearly

b. Providing the opportunity to ask questions in lectures

c. Availability of academic consultation time outside of class hours d. Lecturers remind students of discipline and ethics

e. Fair in treatment of students

f. Willingness to accept criticism and suggestions

\section{Promptness}

a. Lectures are held according to the appropriate number of meetings

b. Lecturer attendance on time

c. There are rules for students to attend lectures on time

d. There are rules on the timeliness of submitting assignments

e. The presence of the lecturer when the course is tested (UTS / UAS)

The reference results above will then be used as guidelines for researchers in analyzing the actualization of lecturer performance in relation to building an academic culture. Furthermore, the questionnaire prepared as a result of a participatory study with the academic community related to academic culture is called the lecturer performance actualization questionnaire.

After conducting a survey with a questionnaire that has been compiled based on input from the academic community in a participatory manner, the results are used to analyze the actualization of lecturer performance in relation to building academic culture. The results of the questionnaire on lecturer performance actualization, 92\% stated the relevance of lecturer performance in building academic culture in the Islamic Religious Education Study Program and Arabic Language Education Study Program. Thus, it can be concluded that the majority can build an academic culture in accordance with the qualifications that are prepared in a participatory manner.

In this study, the actualization of lecturer performance in building an academic culture is described in accordance with the criteria for evaluating the performance of the lecturers, namely; Quality of work (quality of work), 
capability, initiative, communication, timeliness (promtness).

From some of these criteria, it can be explained as follows:

\section{The quality of work}

\section{a. Availability of Syllabus and SAP}

As many as $96 \%$ of respondents stated that lecturers have a syllabus and Lecture Unit (SAP) as a learning guide. The availability of a syllabus is one indicator of a thorough learning preparation from a lecturer who teaches courses. The syllabus becomes guidliness towards the college meeting that will be carried out. This means that in terms of quantity the lecturers in the two study programs have systematic preparation.

b. Availability of course handouts or teaching materials

Handouts or teaching materials are material I discussion materials that are discussed in the implementation of learning. Related to this, $72 \%$ of respondents stated that there were teaching materials delivered by the lecturers.

c. Current materials and approaches (80\%)

Cutting-edge materials and approaches are very important in academic learning. Students will be able to analyze and compare a theory with social facts that are happening. With such an approach, the knowledge that students receive will be more applicable because they know real examples in a case. The results of the study found that $80 \%$ of respondents stated that lecturers used the latest materials and approaches in their learning.

\section{Ability (capability)}

a. Lecturer Qualifications (Scientific Conformity with Subjects)

As many as $88 \%$ of respondents stated that the lecturers who teach in their class are in accordance with scientific qualifications. The qualifications of lecturers can be determined by referring to the educational qualifications possessed by the lecturers, whether they are in accordance with the subject being taught or not. The scientific qualifications of lecturers can also be seen by knowing whether the lecturers' education is still in the same scope or scientific family. The more qualified the lecturers who teach a subject, the better the quality of learning that will be carried out.

b. Mastery of the material

Lecturer qualification indirectly has implications for the lecturers' mastery of the material being handled. Based on the results of the questionnaire, $92 \%$ of the lecturers mastered the material being taught.

c. Mastery in responding to questions during discussion / presentation

One indicator of the lecturers 'mastery of the material is the ability of the lecturer to answer questions that arise in lectures by the lecturer or in group discussions in the lecturers' lectures. Respondents in this case stated that $92 \%$ were able to answer questions during learning. The wider the scope and perspective used by the lecturer in answering, shows the mastery and breadth of knowledge the lecturer has.

\section{d. Class management skills}

The ability to manage classes is one indicator of a lecturer ability. Classroom governance during learning will indirectly be adjusted to the topic or type and learning objectives. This means that lecturers must be dynamically able to condition the class in various situations and learning objectives. $88 \%$ of respondents stated that lecturers have the ability to manage classes.

e. Mastery of media and learning technology

As many as $60 \%$ of respondents said that the lecturers who taught their subjects mastered the media and learning technology. As is known, media and learning technology continue to develop both conventional and up to date. Mastery of the media is very important to keep up with existing developments, so that students become creative and up to date students, and do not become stagnant.

f. Academic assessments carried out objectively

Discriminatory attitudes in learning will 
inevitably create gaps between one student and another. The existence of such a gap will create learning that is not conducive to psychological influences. $80 \%$ of respondents stated that the lecturers' fair attitude objectively in the assessment showed that learning in the PAI and PBA study programs was quite conducive.

\section{Initiatives}

a. The syllabus is the result of the coordination of parallel courses

In a lecture, it is not uncommon to find the same courses in a study program that are taught by different lecturers from one class to another. So to equate material standards and learning objectives between different classes, the department directs a consortium of scientific clumps. This is to avoid inequality of course material between one another in the same course. $56 \%$ of respondents said the syllabus delivered by the lecturer was the result of a consortium with other lecturers in their respective subjects. This means that there are still very few lecturers who are aware of the importance of a consortium of scientific lecturers.

b. Standardization of exam questions for the same subject with different lecturers

The existence of a consortium of course lecturers is also important in determining the same examination standards for the same course even though there are different classes, this is to avoid scientific imbalances between one class and another. $72 \%$ of respondents stated that there were similarities in the exam material between one class and another even though there were different teachers.

c. Paper writing rules are in accordance with academic writing guidelines

As many as $92 \%$ of respondents acknowledged that there were rules for writing papers according to academic writing guidelines. Writing paper according to academic rules will indirectly affect their sensitivity in writing. Even consistent academic writing is a form of habituation, so that students have no difficulty in preparing their final assignments.

d. Foreign language reference suggestions
Another important thing that cannot be forgotten by lecturers is to recommend foreign language references in assignments prepared by students. Extensive knowledge and various references related to foreign language references will make students not narrow-minded so that it will lead to scientific stagnation. The majority of lecturers have encouraged students to use foreign language references (84\%).

e. Tasks that are analytical, research, or product manufacturing

A total of $52 \%$ of student respondents stated that the assignment given by the lecturer was in the form of analysis, research or product manufacture. This will stimulate students to be creative and independent and to be active in implementing their theoretical knowledge in a case or product. However, a small percentage indicates that lecturers are less oriented towards student academic independence, especially in case studies.

f. Involving students in the study of academic activities

Lecturers need to involve students in studies and academic activities. This is nothing but to provide academic stimulation for students related to scientific discourse in accordance with their field of competence. From this study, 60 respondents indicated that lecturers involved students in academic discussion activities.

\section{Communication}

a. Delivering lecture materials properly and clearly

As many as $88 \%$ of students said that lecturers could deliver lecture material well and clearly. The material presented by the lecturer theoretically will be a provision of knowledge and a source of discussion material in learning. Unclear delivery will reduce academic dynamics in learning.

b. Providing the opportunity to ask questions in lectures

Lecturers regularly need to provide opportunities for students to ask questions, both 
related to the material presented and related material. $76 \%$ of students stated that lecturers in learning provide time for students to ask questions.

c. Availability of academic consultation time outside of class hours

Students can carry out further discussions related to learning material in class. $72 \%$ of students stated that the lecturers who taught courses in their class had provided academic consulting opportunities outside the classroom.

d. Lecturers remind students of discipline and ethics

Lecturers in accordance with respondents' statements, $84 \%$ also reminded students that discipline and ethics were not appropriate in the academic environment. This shows the lecturer's attention to grades, not just stopping at the realm of the formality of knowledge transfer in the classroom.

e. Fair in treatment of students

As many as $80 \%$ of respondents stated that lecturers were fair in treating students. Such attitudes need to be maintained and continued so as not to create discriminatory feelings in conducive learning.

f. Willingness to accept criticism and suggestions

The results of the questionnaire show that only $68 \%$ of lecturers have the willingness to be criticized and given suggestions. The criticism made by students is a form of student attention that needs to be appreciated.

\section{Punctuality (promtness)}

a. Lectures are held according to the appropriate number of meetings

Based on the results of the questionnaire it was found that in general only $44 \%$ of lecturers carried out the learning according to the number of meetings that should have been. This is certainly an important finding where the majority of lecturers do not carry out lectures according to the number of meetings they should have. So that the Study Program needs to make further clarification about the reasons and reasons for lecturer absences according to the number of meetings that should be.

b. Lecturer attendance on time

As many as $88 \%$ of respondents provided information regarding the discipline of lecturer attendance in learning on time. The presence of lecturers on time is an indication of a high commitment to carry out learning optimally. The spirit of good dedication is an example for students in implementing discipline.

c. There are rules for students to attend lectures on time

Discipline commitment is also applied to students. As many as $84 \%$ of students stated that the lecturers applied the rules so that students were present on time. Good discipline will create uninterrupted teaching and learning activities. This applies to lecturers and students, thus creating trust between lecturers and students.

$\mathrm{d}$. There are rules on the timeliness of submitting assignments

In addition, students are also led to collect assignments on time. This is to require students to be disciplined and consistent in carrying out the assignments given by the lecturer. In this case, $84 \%$ of respondents stated that lecturer discipline requires students to submit assignments on time. Good militancy will form a firm and accountable character of students.

e. The presence of the lecturer when the course is tested (UTS / UAS)

One of the academic commitments shown by the lecturer is the contribution to participate in supervising the course of the examination of the subjects being taught. $72 \%$ of students stated that lecturers participated in monitoring directly by being present in the exam room when their subjects were tested. The presence of lecturers in the exam room also gives enthusiasm and accountability as well as student confidence in the responsibility of the lecturer. After carrying out an analysis related to the actualization of lecturer performance in building an academic culture in the Islamic Religious Education Study Program and Arabic Language Education, it will become 
an evaluation and input in the management of the two study programs.

The evaluation will be a reference in improving and improving the quality of existing management. The evaluation notes that need to be followed up because of the gap between the ideals and the reality of the lecturer's performance in shaping the academic culture are; The syllabus is the result of the coordination of parallel courses (56\%). Tasks that are analysis, research, or product creation $(52 \%)$. Lectures are held according to the number of meetings that should be $(44 \%)$.

\section{CONCLUSION}

Based on the results and discussion above research, it can be concluded that the quality of the performance of lecturers in the Islamic Religious Education Study Program and Arabic Language Education FTIK IAIN Pekalongan, when viewed from the Lecturer Performance Index (IKD) of the Islamic Religious Education Study Program as a whole fulfills above a minimum score of 7 . the details are; the highest score was 9.70, the lowest score was 8.60 and the average score was 9.30. The overall Lecturer Performance Index (IKD) of the Islamic Religious Education Study Program meets the minimum score above 7 . The details are; the highest value was 9.77, the lowest value was 8.35 and the average value was 9.28. The quality of the performance of the lecturers of the Islamic Religious Education Study Program and Arabic Language Education based on the Lecturer Performance Index (IKD) of the IAIN Pekalongan is worthy of a value above 7 . The relationship between lecturer performance and the formation of academic culture in the Islamic Religious Education and Education Study Program In Arabic as obtained from the results of the questionnaire, $92 \%$ stated that there was a relevance between the two. The results of the evaluation of this study, there are still things that need to be improved in fact actualization in building an academic culture in the Islamic
Religious Education Study Program and Arabic Language Education. The highest obstacle obtained from this study is that the lecturer in carrying out lectures does not match the number of meetings that the lecturer should hold (44\%). In addition, there needs to be a special increase in terms of initiative (initiative), namely the syllabus is the result of the coordination of parallel courses and tasks that are analysis, research, or product creation.

\section{REFERENCES}

[1] Ali, H. Muhammad. 1993. Pendidikan Strategi Penelitian. (Bandung: Angkasa)

[2] Departemen Pendidikan Nasional. 2001. Kamus Besar Bahasa Indonesia. (Jakarta: Balai Pustaka)

[3] Ekaviana, Dessy and Nurkhin, Ahmad. 2016. "The Effect of Input Quality, School Environment and Future orientation on Students' Accounting Competence". Journal of Humanities and Social Science. Volume. 21. Issue. 8. Ver. 3.

[4] Furchan, Arief. 2004. Pengantar Penelitian dalam Pendidikan. (Yogyakarta: Pustaka Pelajar)

[5] Griffin, W. Ricky. 2015. Management. (Boston: Houghton Mifflin Company).

[6] Haseena, and Mohammed, Ajims P. 2015. "Aspects of Quality in Education for the Improvement of Educational Scenario". Journal of Education and Practice. Vol. 6. No. 4.

[7] Hoque, Kazi Enamul, et al. 2020. "Relationships between Supervision and Teachers' Performance and Attitude in Secondary Schools in Malaysia". journals.sagepub.com. DOI: $10.1177 / 2158244020925501$.

[8] Ismail, Izwah binti. 2018. "An Important Role of Educational Supervision in The 
Digital Age". The International Journal of Counseling and Education. Vol. 3. No. 4.

[9] Istikomah, Dhian Arista, and Ayuwanti, Irma. 2017. "Improving The Quality Of School As A Solutions Of Education Problem". Proceeding. International Conference on Educational Research and Innovation.

[10] Khun-inkeeree, Hareesol, et al. 2019. "Effects of Teaching and Learning Supervision on Teachers Attitudes to Supervision at Secondary School in Kubang Pasu District, Kedah". International Journal of Instruction. Vol. 12. No. 1.

[11]Lembaga Penjaminan Mutu IAIN Pekalongan. 2020. Pedoman Pengukuran Indeks Kinerja Dosen (IKD) IAIN Pekalongan. (Pekalongan; Lembaga Penjaminan Mutu IAIN Pekalongan)

[12] Maliki, Zaenudin. 2010. Sosiologi Pendidikan. (Yogyakarta: Gajah Mada University Press)

[13] Muhab, Sukro. 2010. dll. Standar Mutu Sekolah Islam Terpadu Jaringan Sekolah Islam Terpadu. (Jakarta. JSIT)

[14] Nasution, M. N. 2005. Manajemen Mutu Terpadu dalam Kualitas Pelayanan. (Bogor: Ghalia Indonesia)

[15] Nasution, Syukri Albani. dan Muhammad. dkk.. 2015. Ilmu Sosial dan Budaya Dasar. (Jakarta: Rajawali Pers).

[16] Nursaid. 2020. "The Leadership of Headmaster in Improving The Quality of Madrasa Education". Jurnal Pendidikan Islam. Vol. 6. No. 1.

[17] Sallis, Edward. 2012. "Total Quality Management in Education". Manajemen Mutu Pendidikan. Jogyakarta: IRCiSoD.

[18] Sen, Amartya. "Equality of What?" dalam The Tanner Lecture of Human Values.
1980. (Cambridge: Cambridge University Press)

[19] Undang-Undang Republik Indonesia Nomor 14 Tahun 2005.

[20] Undang-Undang Republik Indonesia Nomor 20 Tahun 2003. 